\title{
Estimation of the number of preventable COVID-19 deaths in relation to the restrictive measures adopted in Europe
}

José A. Cernuda-Martínez * and Andrea Fernández-García²

${ }^{1}$ Faculty of Nursing, Universidad de Oviedo, Gijon; ${ }^{2}$ Health Service, Principality of Asturias, Spain

\begin{abstract}
Introduction: In December 2019, a new coronavirus emerged in Wuhan, China, which has become a global health problem. Objectives: To estimate how many daily COVID-19 deaths per 100,000 population could have been avoided if each one of five restrictive measures had been implemented at the time the first case was diagnosed, and to estimate a multiple linear regression model predictive of the number of deaths per 100,000 population. Methods: A simple linear regression was performed between the days elapsed since the first COVID-19 diagnosed case, implementation of each one of the five restrictive measures carried out by the 39 European studied countries, the number of hospital beds per 1,000 population (independent variables) and the number of COVID-19 deaths per 100,000 population. Results: For each day elapsed from the first COVID-19 reported case to the adoption of restrictive measures, between $0.611(p=0.004)$ and $1.863(p=0.000)$ patients died per 100,000 population, depending on the implemented measure. Conclusions: Restrictive measures and social distancing, as well as promptness of their implementation, are necessary for achieving a decrease in COVID-19 infections and mortality.
\end{abstract}

KEY WORDS: COVID-19. Mortality. Public health. Virus. Prevention and control.

\section{Estimación del número de fallecimientos evitables por COVID-19 en relación con las medidas restrictivas adoptadas en Europa}

\section{Resumen}

Introducción: En diciembre de 2019 surgió un nuevo coronavirus en Wuhan, China, que se ha convertido en un problema de salud global. Objetivo: Estimar cuántos fallecimientos diarios atribuibles a COVID-19 por cada 100000 habitantes se podrían haber evitado si se hubiese llevado a cabo cada una de las cinco medidas restrictivas al momento del diagnóstico del primer caso, así como estimar un modelo de regresión lineal múltiple predictivo del número de fallecimientos por cada 100000 habitantes. Métodos: Se realizó un modelo de regresión lineal simple entre los días transcurridos desde el primer caso diagnosticado de COVID-19, la implantación de cada una de las cinco medidas llevadas a cabo por los 39 países europeos estudiados, el número de camas hospitalarias por 1000 habitantes (variables independientes) y el número de fallecimientos por COVID-19 por 100000 habitantes. Resultados: Por cada día transcurrido desde el primer caso notificado de COVID-19 hasta la adopción de las medidas restrictivas, fallecieron entre $0.611(p=0.004)$ y $1.863(p=0.000)$ pacientes por cada 100000 habitantes, dependiendo de la medida implementada. Conclusiones: Las medidas restrictivas y el distanciamiento social, así como la celeridad de su instauración, son necesarios para lograr el descenso del número de contagios de COVID-19 y su mortalidad.

PALABRAS CLAVE: COVID-19. Mortalidad. Salud pública. Virus. Prevención y control.

\footnotetext{
Correspondence:

*José A. Cernuda-Martínez

E-mail: jacernudam@gmail.com

Gac Med Mex. 2021;157:271-276

Contents available at PubMed

www.gacetamedicademexico.com

0016-3813/@ 2020 Academia Nacional de Medicina de México, A.C.. Published by Permanyer. This is an open access article under the CC BY-NC-ND license (http://creativecommons.org/licenses/by-nc-nd/4.0/).
} 


\section{Introduction}

In December 2019, a new coronavirus emerged in Wuhan, China, which has become a global health problem: ${ }^{1}$ SARS-CoV-2, belonging to the same family as SARS and MERS-CoV, all of them responsible for zoonotic infections, the first one, for COVID-19, and the third one, for Middle East respiratory syndrome. ${ }^{2}$

SARS-CoV-2 is a virus with a positive single-stranded RNA genome of approximately $30 \mathrm{~kb}$, which has 74 to $99 \%$ coincidence with the strands of the pangolin (Manis javanica) and horseshoe bat (Rhinolophus sinicus) coronaviruses. ${ }^{1,3-5}$ SARS-CoV-2 genome sequences are similar to those of SARS-CoV; however, there are certain differences such as the lack of the coding region for protein 8 in SARS-CoV-2, which might result in lower pathogenesis in comparison with SARS-CoV. ${ }^{6}$

SARS-CoV-2 transmission occurs from person to person through respiratory droplets, which are expelled when an infected person coughs or sneezes. Larger aerosols with higher contagious capacity can be generated in hospitals and closed spaces, where the virus persists for several hours, hence the need to restrict contact between people in order to prevent the spread of the virus. ${ }^{7}$

\section{Objectives}

- To estimate how many COVID-19-attributable daily deaths per 100,000 population could have been avoided if each one of the five restrictive measures established by European countries would have been adopted at the time the first case was diagnosed.

- To estimate a multiple linear regression model predictive of the number of COVID-19-attributable deaths per 100,000 population with regard to the five restrictive measures.

\section{Methods}

An ecological study was designed in August 2020 involving 39 European countries. The inclusion criterion was having access to the data of all implemented measures that were included in the study. The date of first official COVID-19 diagnosis was established as the starting point ${ }^{8}$, and the number of days from its occurrence to the implementation of the following five measures was quantified:9
- Border closure.

- Closure of non-essential business.

- Closure of leisure and hospitality establishments.

- Prohibition of events and concentrations.

- Face-to-face classes suppression.

The rate of COVID-19 deaths per 100,000 population by June 20, 2020 was obtained for each one of

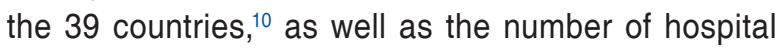
beds per 1,000 population..$^{11,12}$

\section{Statistical analysis}

A simple linear regression model of the relationship between each one of the independent variables (days elapsed from the first case to border closure, days elapsed from the first case to the closure of non-essential business activities, days elapsed from the first case to the closure of leisure and hospitality establishments, days elapsed from the first case to the prohibition of events and concentrations, days elapsed from the first case to face-to-face classes suppression and number of hospital beds per 1000 population) and the dependent variable (rate of COVID-19 deaths per 100,000 population) was constructed in order to know the number of deaths per 100,000 population that could have been avoided each day if the restrictive measures would have been adopted at the time the first case was diagnosed.

On the other hand, a simple linear regression model of the relationship between the rate of COVID-19 deaths and the number of available hospital beds was generated, as well as a multiple linear regression predictive model between the number of deaths per 100,000 population (dependent variable) and the days elapsed from the first case to the prohibition of events and concentrations, given that the World Health Organization indicates that physical distancing and hand hygiene are the best preventive measures. ${ }^{13}$ This model was adjusted for the other independent variables, using the method of best model selection based on all equations. To select the final model, Mallows's $\mathrm{Cp}$ criterion was used, with the model with the lowest value being selected.

A level of significance with a $p$-value $<0.05$ and a a $95 \%$ confidence index were considered. To externally assess the reliability of the model, prediction loss was evaluated using the shrinkage method, which consists of calculating the difference between the square of the multiple correlation coefficient of the model estimated in the derivation group $\left(R^{2}\right)$ and the square of the simple correlation coefficient 
between the predicted value with the estimated model in the derivation group and the dependent variable $(\mathrm{Y})$, calculated in the validation group $\left(\mathrm{r}^{2}\right)$. A difference $\leq 0.1$ was assumed to be acceptable. Analyses were carried out with the Stata program, version 15.

\section{Results}

Table 1 indicates the date the first official COVID-19 diagnosis took place on each one of the 39 analyzed European countries, the days elapsed until the implementation of each one of the five restrictive measures, the number of COVID-19 deaths per 100,000 population and the number of available hospital beds per 1,000 population.

Table 2 shows the b-coefficient obtained after the linear regression between the independent variable and each one of the dependent variables. Each b-coefficient expresses the number of daily deaths per 100,000 population that would have been avoided if each preventive measure would have been adopted on the day of the first COVID-19 diagnosis.

Table 3 describes the variables included in the predictive model, as well as their $95 \%$ confidence intervals and $p$-value. Mallows's Cp value was 3.04 , adjusted $R^{2}$ value was 0.538 , and the prediction loss value (difference between $R^{2}$ and $r^{2}$ or shrinkage) was $-1.209 \times 10^{-8}$.

\section{Discussion}

The purpose of this study was to estimate how many daily COVID-10 deaths per 100,000 population could have been prevented if each measure would have been taken at the time the first case was diagnosed. According to the results of this study, failure to adopt each one of the analyzed restrictive measures causes an increase of 0.611 to 0.929 deaths per 100,000 population for every 24 hours of delay in their implementation since the first case official diagnosis. This number of preventable deaths is statistically significant.

The Imperial College London showed that a combination of isolation of cases and voluntary quarantine for three months might prevent $31 \%$ of deaths, in comparison with an epidemic without any control measures. Adding social distancing of people aged 70 years and older for four months would increase averted deaths to $49 \%$. The combination of isolation of cases, home quarantine, social distancing of the entire population, and closure of schools and universities was considered to be the most effective combination to reduce the reproduction number to a value close to one. ${ }^{14}$

Although more comprehensive and stringent prevention and control measures are more effective for COVID-19 containment, at some point the incremental effect of adding another restrictive measure is only minimal and should be weighed against negative collateral effects, such as social and economic consequences for communities that have been subjected to the measures for long periods, which could also lead to an increased burden on health in general. ${ }^{15}$

For the control of the epidemic in Europe, some researchers defined three scenarios based on mathematical models that predict quite accurately the projection of the epidemic and the demand for health resources during the time of the exponential curve: ${ }^{16}$

- No mobility restrictions.

- Partial restrictions.

- Full restrictions that only allow essential services activity.

Based on these three scenarios, the impact of the epidemic evolution on the number of cases and of those who will require conventional hospitalization or admission to an intensive care unit is predicted. This also gives rise to the recommendation to apply these mobility restrictions according to the number of cases in the region, based on which two types of areas are defined:

- Type A area, with $\geq 100$ cases per 100,000 population on last week, where establishing complete closure of activities for at least 15 to 21 days is recommended.

- Type B area, with < 100 cases per 100,000 population, where implementing partial confinement and reducing activities to $30 \%$ and internal mobility to $25 \%$ is recommended.

These measures should be accompanied by social distancing and diagnostic tests in cases where infection is suspected. Implementation of measures of this type has achieved a gradual reduction in the number of cases in three to four weeks. ${ }^{16}$

Assuming that strict distancing and confinement measures contribute to a decrease in the number of cases and, consequently, of deaths, the following steps should be directed at how to de-escalate the imposed restrictive measures. If due to the enormous social and economic costs of confinement the quarantine was prematurely terminated, there would be a return to the initial scenario where the epidemic exponentially spreads again. ${ }^{17}$ 


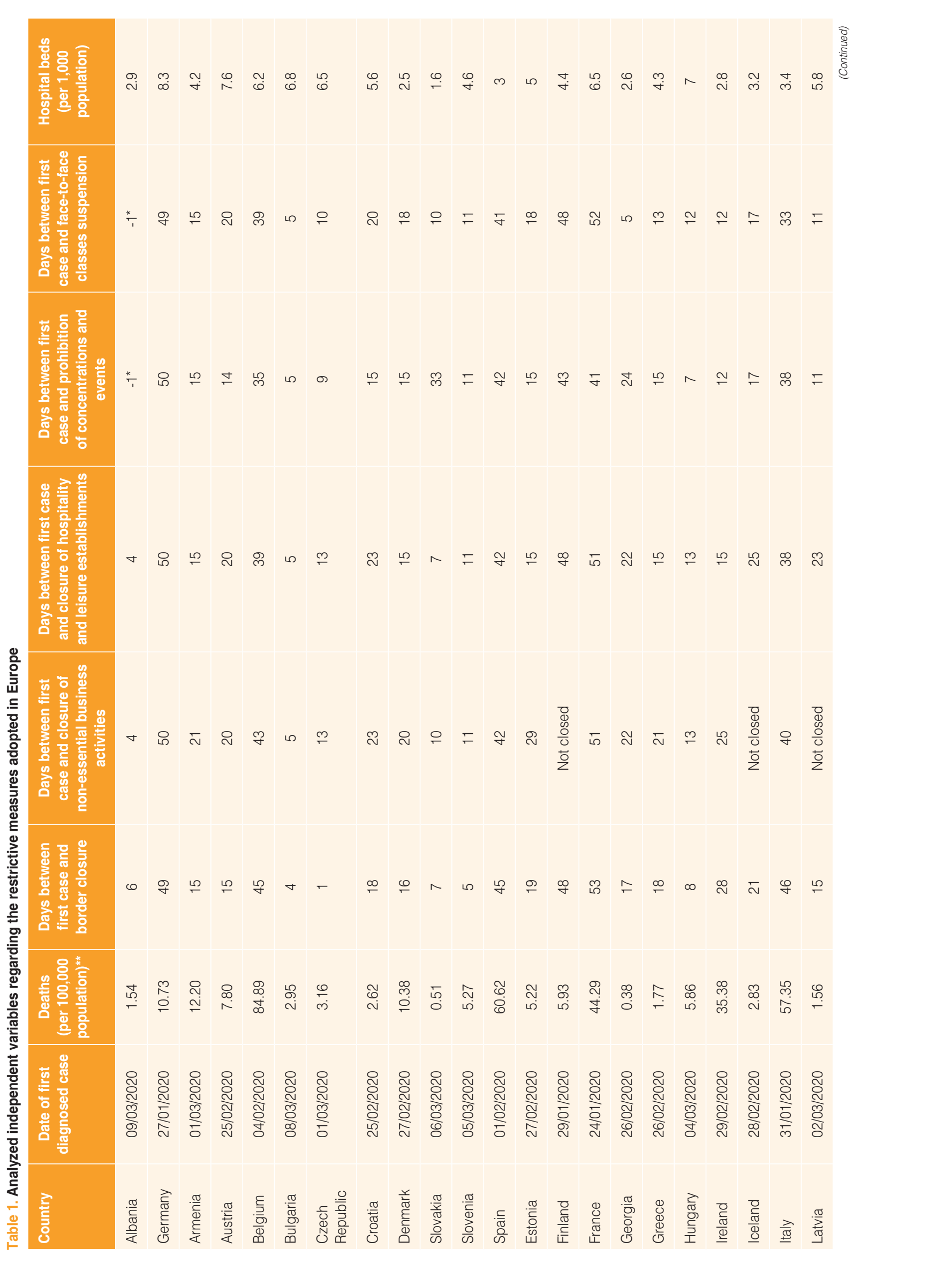


Cernuda-Martínez JA, Fernández-García A: Avoidable COVID-19 deaths in Europe

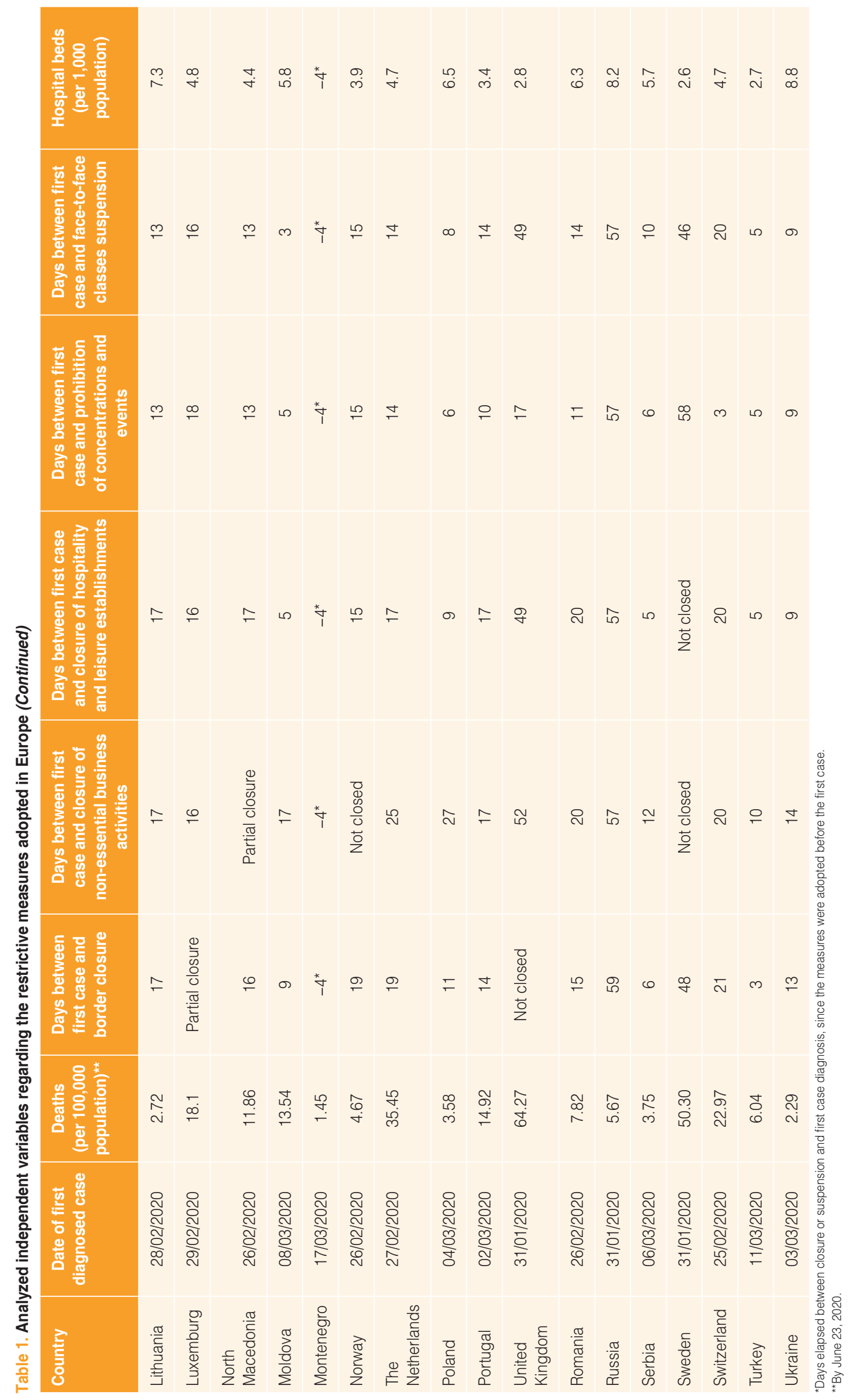


Table 2. b-coefficients of the simple linear regression between each independent variable and the dependent variable (COVID-19attributable deaths per 100,000 population)

\begin{tabular}{|c|c|c|c|c|}
\hline \multirow[t]{2}{*}{ Independent variable } & \multirow[t]{2}{*}{ b-coefficient } & \multicolumn{2}{|c|}{$95 \%$ Cl } & \multirow[t]{2}{*}{ p } \\
\hline & & $\begin{array}{l}\text { Lower } \\
\text { limit }\end{array}$ & $\begin{array}{c}\text { Upper } \\
\text { limit }\end{array}$ & \\
\hline $\begin{array}{l}\text { Days between first } \\
\text { diagnosed case and } \\
\text { border closure }\end{array}$ & 0.780 & 0.446 & 1.114 & $0.000^{*}$ \\
\hline $\begin{array}{l}\text { Days between first } \\
\text { diagnosed case and } \\
\text { closure of non-essential } \\
\text { businesses }\end{array}$ & 0.929 & 0.512 & 1.347 & $0.000^{*}$ \\
\hline $\begin{array}{l}\text { Days between first } \\
\text { diagnosed case and } \\
\text { closure of leisure and } \\
\text { hospitality establishments }\end{array}$ & 0.739 & 0.350 & 1.127 & $0.000^{*}$ \\
\hline $\begin{array}{l}\text { Days between first } \\
\text { diagnosed case and } \\
\text { prohibition of events and } \\
\text { concentrations }\end{array}$ & 0.611 & 0.208 & 1.015 & $0.004^{*}$ \\
\hline $\begin{array}{l}\text { Days between first } \\
\text { diagnosed case and } \\
\text { face-to-face classes } \\
\text { suspension }\end{array}$ & 0.786 & 0.427 & 1.145 & $0.000^{*}$ \\
\hline $\begin{array}{l}\text { Hospital beds per 1,000 } \\
\text { population }\end{array}$ & -2.348 & -6.072 & 1.376 & 0.209 \\
\hline
\end{tabular}

Table 3. Coefficients of the variables of the estimated model of preventable COVID-19 deaths and restrictive measures

\begin{tabular}{|c|c|c|c|c|}
\hline \multirow{2}{*}{$\begin{array}{l}\text { Independent variable } \\
\text { included/model } \\
\text { constant }\end{array}$} & \multirow[t]{2}{*}{ b-coefficient } & \multicolumn{2}{|c|}{$95 \% \mathrm{Cl}$} & \multirow[t]{2}{*}{$\mathbf{P}$} \\
\hline & & $\begin{array}{l}\text { Lower } \\
\text { limit }\end{array}$ & $\begin{array}{l}\text { Upper } \\
\text { limit }\end{array}$ & \\
\hline Constant & 12.527 & -3.229 & 27.886 & 0.111 \\
\hline $\begin{array}{l}\text { Days between first } \\
\text { diagnosed case and } \\
\text { prohibition of events and } \\
\text { concentrations }\end{array}$ & -0.672 & -1.429 & 0.079 & 0.080 \\
\hline $\begin{array}{l}\text { Days between first } \\
\text { diagnosed case and } \\
\text { border closure }\end{array}$ & 1.421 & 0.672 & 2.175 & $0.001^{*}$ \\
\hline $\begin{array}{l}\text { Hospital beds per 1,000 } \\
\text { population }\end{array}$ & -3.016 & -5.820 & -0.192 & $0.037^{*}$ \\
\hline
\end{tabular}

*Statistically significant value.

\section{Conclusions}

An adequate healthcare system, well-trained professionals and adequate restrictive and social distancing measures are essential for reducing the number of COVID-19 infections, as well as their mortality rates. The earlier the restrictive measures are implemented, the lower the number of deaths due to SARS-CoV-2 infection will be.

\section{Conflict of interests}

The authors declare that they have no conflicts of interest.

\section{Funding}

This research did not receive any specific grants from agencies of public, commercial or non-profit sectors.

\section{Ethical disclosures}

Protection of human and animal subjects. The authors declare that no experiments were performed on humans or animals for this research.

Confidentiality of data. The authors declare that no patient data appear in this article.

Right to privacy and informed consent. The authors declare that no patient data appear in this article.

\section{References}

1. Zhu N, Zhang D, Wang W, Li X, Yang B, Song J, et al. A novel coronavirus from patients with pneumonia in China, 2019. N Engl J Med. 2020;382:727-733.

2. Ji W, Wang W, Zhao X, Zai J, Li X. Cross-species transmission of the newly identified coronavirus 2019-nCoV. J Med Virol. 2020;92:433-440.

3. Zhang Y. [The epidemiological characteristics of an outbreak of 2019 novel coronavirus diseases (COVID-19) in China]. Zhonghua Liu Xing Bing Xue Za Zhi. 2020;41(2):145-151.

4. Zhou P, Yang XL, Wan XG, Hu B, Zhang L, Zhang W, et al. A pneumonia outbreak associated with a new coronavirus of probable bat origin. Nature. 2020;579:270-273

5. Chen L, Liu W, Zhang Q, Xu K, Ye G, Wu W, et al. RNA based mNGS approach identifies a novel human coronavirus from two individual pneumonia cases in 2019 Wuhan outbreak. Emerg Micro Infect. 2020;9:313-319.

6. Wu A, Peng Y, Huang B, Ding X, Wang X, Niu P, et al. Genome composition and divergence of the novel coronavirus (2019-nCoV) originating in China. Cell Host Microbe. 2020;27:325-328.

7. Carod-Artal FJ. Complicaciones neurológicas por coronavirus y COVID-19. Rev Neurol. 2020;70: 311-322.

8. Mamoon N, Rasskin G. Covid visualizer. USA: Carnegie Mellon University [Internet]; 2020

9. Barcelona Centre for International Affairs [Internet]. Spain: COVID-19: la respuesta de Europa contra la pandemia; 2020.

10. Johns Hopkins University/Coronavirus Resource Center [Internet]. USA: Mortality analyses; 2020.

11. Banco Mundial [Internet]. USA: Médicos por cada 1000 personas; 2020.

12. Banco Mundial [Internet]. USA: Camas hospitalarias por cada 1000 personas; 2020

13. Organización Mundial de la Salud. [Internet]. Switzerland: Consideraciones relativas a los ajustes de las medidas de salud pública y sociales en el contexto de la COVID-19; 2020

14. Ferguson NM, Laydon D, Nedjati-Gilani G, Imai N, Ainslie K, Baguelin M, et al. Report 9 - Impact of non-pharmaceutical interventions (NPIs) to reduce COVID19 mortality and healthcare demand. United Kingdom: Imperial College London; 2020.

15. Nussbaumer-Streit B, Mayr V, Dobrescu Al. Quarantine alone or in combination with other public health measures to control COVID-19: a rapid review. Cochrane Database Syst Rev. 2020;4:CD013574.

16. Mitjà $O$, Arenas A, Rodó X. Experts' request to the Spanish Government: move Spain towards complete lockdown. Lancet. 2020;395:1193-1194.

17. Prem K, Liu Y, Russell TW, Kucharski AJ, Eggo RM, Davies N, et al. The effect of control strategies to reduce social mixing on outcomes of the COVID-19 epidemic in Wuhan, China: a modelling study. Lancet Public Health. 2020:5:e261-e270 